\title{
PREVALENCE AND RISK FACTORS OF BOVINE TUBERCULOSIS IN CATTLE IN MYMENSINGH SADAR
}

\author{
M. A. H. Mondal, M. S. Parvin, S. C. Sarker' ${ }^{1}$ A. K. M. A. Rahman and M. T. Islam*
}

Department of Medicine, Faculty of Veterinary Science, Bangladesh Agricultural University Mymensingh-2202, Bangladesh

\begin{abstract}
Bovine tuberculosis (bTB) is a disease of zoonotic importance as well as high priority all over the world. Risk factors for bovine tuberculosis in cattle are not well investigated in Bangladesh. Therefore, the objective of this study was to identify the associated risk factors for bTB along with determination of prevalence in cattle of Mymensingh Sadar. A cross-sectional study was carried out to elucidate on 101 cattle from 56 households during January to May 2012. The direct interview using a questionnaire and physical examination of cattle was performed to collect farm and animal level data. Besides data collection, blood samples were collected from study cattle and subjected to immunochromatographic assay (ICGA) by using Anigen Rapid Bovine TB Ab test kit for the diagnosis of bTB. Risk factors analysis was done using bivariable followed by multiple logistic regression with stepwise backward elimination method. The results of the study revealed an overall tuberculosis prevalence of $5.9 \%$. Multiple logistic regression analysis revealed significant association of bovine tuberculosis with herd size (more than 4) (Odds Ratio, $\mathrm{OR}=5.9, \mathrm{p}=0.03)$ and history of coughing $(\mathrm{OR}=8.9, \mathrm{p}=0.005)$. The effect of herd size (more than 4) could be minimized by maintaining the cattle in a herd with adequate floor space and better ventilation facilities as it would not be practicable to keep the herd size minimum. Further study should be done to find out more associated risk factors for the occurrence of bTB.
\end{abstract}

Key words: Prevalence, bovine tuberculosis, cross-bred dairy cattle, risk factors

\section{INTRODUCTION}

Bovine tuberculosis (bTB) is a zoonotically important disease that can infect wide variety of animal species and can be transmitted from animals to humans (O'Reilly and Daborn, 1995). The bTB is caused by Mycobacterium bovis that has a wide host range and is found responsible for disease in free-living wildlife, captive wildlife including farmed deer, domestic livestock (cattle, goats, water buffalo, camels, alpacas, llamas, etc), non-human primates and humans (O'Reilly and Daborn, 1995). This disease has socio-economic and public health importance and is of great significance to international trade of animals and animal products (OIE, 2004). This disease not only poses a threat to the economy of developing countries but also remains a problem in developed world (Khan et al., 2008). The bTB is a chronic contagious debilitating disease of animals associated with progressive weakness/emaciation and tubercle (granuloma) formation, mainly confined to respiratory system (primarily in the lungs) and occasionally in other organs (Menzies and Neill, 2000). The infection to bovine can occur through the colostrum/milk to calves, ingestion of feed contaminated with feces of infected animals, aerosol, contact with each other and other wildlife (Polyakov et al., 1994). The causative agent of tuberculosis (Mycobacterium) can remain viable in the environment/soil for about two years (Hutchings and Harris, 1997). Various risk factors responsible for the occurrence of disease include calving site, herd size, the length of time calves kept in groups, the breed, the source of replacement, presence of wild animals and the region in which they are kept, presence of mixed (dairy and beef) production, age, housing systems (Cetinkaya et al., 1997). In the Indian subcontinent, the prevalence of bTB varies in different parts and during different months of the year (Khan et al., 2008). The prevalence of bTB in cattle has been reported as $5.9 \%$ and $3.05 \%$ in Pabna and Mymensingh district, respectively (Pharo et al., 1981; Samad and Rahman, 1986) while, in breeding bull it is reported as $27.5 \%$ (Islam et al., 2007). However, recent study showed 30\% prevalence of bTB in Red Chittagong cattle (Rahman and Samad, 2008). In our neighboring countries like Nepal and India, 39\% and 7.6\% prevalence was reported in buffalo, respectively (Chandra et al., 2007; Joshi et al., 1976). The disease can be diagnosed by using various tests including tuberculin test, serum immunoglobulin $\mathrm{G}$ test, histopathology,

Present Address: ${ }^{1}$ Veterinary Surgeon, Upazila Livestock Office, Kaharol, Dinajpur, Bangladesh

*Corresponding e-mail address: taohid.bau@gmail.com

Copyright (C 2014 Bangladesh Society for Veterinary Medicine

All rights reserved 0308/2014 


\section{Mondal and others}

Enzyme Linked Immunosorbent Assay (ELISA), immunochromatographic assay (ICGA), Latex bead agglutination assay (LBAA) and PCR (Jark et al., 1997; Costello et al., 1998; Valente et al., 1997; Aranaz et al., 1996). Among them tuberculin test has been frequently used for the screening purpose (Islam et al., 2007). In tuberculin test the purified protein derivative (PPD) of Mycobacterium is used for single intradermal (SID) injection and the reaction read between 48 and 96 hours after injection and a positive reaction constitutes a diffuse swelling at the injection site (Radostits et al., 2000). However, many limitations to the SID tuberculin test have been reported for the diagnosis of bTB (Koo et al., 2005). To overcome the limitations of tuberculin test, Enzyme Linked Immunosorbent Assay (ELISA), immunochromatographic assay (ICGA) and the Latex bead agglutination assay (LBAA) have been evaluated for serodiagnosis of bTB with high sensitivity and specificity (Koo et al., 2005). Among these three serodiagnostic tests, ICGA (Anigen Rapid Bovine TB Ab test kit, Bionote Inc, Korea) used in this study requires only 20 minutes to produce test reaction. According to the manufacturer leaflet this test kit has been compared with a PPD test and found to identify $M$. bovis antibodies in specimens with a high degree of accuracy. By using the same test kit Rahman and Samad (2008) determined the prevalence of bTB in Red Chittagong cattle (RCC) in Bangladesh. Earlier studies from Bangladesh mostly concentrated on the prevalence of bTB (Rahman and Samad, 2008; Samad and Rahman, 1986; Islam et al., 2007; Pharo et al., 1981). However, to the best of our knowledge, risk factors for the prevalence of bovine tuberculosis in cattle are not well investigated in Bangladesh. Considering the above facts the present research work was undertaken with the following objectives: (i) to determine the prevalence of bovine tuberculosis in cattle of Mymensingh Sadar and (ii) to identify the risk factors associated with bovine tuberculosis in cattle of Mymensingh Sadar.

\section{METERIALS AND METHODS}

\section{Study area}

The study was carried out in 6 villages of Mymensingh Sadar, namely Nijkalpa, Salakandi, Kewatkhali, Bolashpur, Digarkanda and Badekolpa situated within $10 \mathrm{~km}$ around Bangladesh Agricultural University (BAU). The city of Mymensingh stands on the bank of Old Brahmaputra River.

\section{Study design}

A cross-sectional observational study was carried out to determine the seroprevalence of bTB in dairy cattle registered under Seed Bull Production Project of Animal Breeding and Genetics Department, BAU. The study was carried out between January and May 2012.

\section{Study animals and husbandry practices}

There are 135 dairy cattle registered for the seed bull production project of Animal Breeding and Genetics Department, BAU, Mymensingh. Our target was to screen all of 135 animals for bovine tuberculosis but blood samples were collected from 101 animals. The owners of other animals disagreed to provide blood samples. The range of daily milk yield of cross-bred cows is 8-20 liters and indigenous cows are 2-4 liters. The cattle management system in the area is small-scale dairy with traditional crop-based subsistence farming systems. The small-scale dairy system mainly practices zero grazing (Intensive) with occasional semi-zero (Semi-Intensive) and tethering systems (Extensive). The feeding practice is a 'cut-and-carry system'. Green grasses provided are mainly road side grass. Paddy straw is the common roughage for all the cows. Adequate amount of concentrates including wheat bran, rice polish and oil cakes are provided with roughages. Vitamin mineral premixes are also added to ration irregularly. The common breeds are indigenous and their crosses with Holstein Friesian and Sahiwal. Manure removal is made on a daily basis and milking is done by hand.

\section{Collection of serum samples}

About $7 \mathrm{ml}$ of blood was collected from jugular vein from each cattle in a disposable sterile syringe. The blood containing syringes were kept at room temperature at $45^{\circ}$ angle for one hour for maximum clotting. Then the clotted blood containing syringes were kept in refrigerator $\left(4^{\circ} \mathrm{c}\right)$ for overnight to get maximum serum yield and after centrifugation serum was separated by conventional method and stored at $-20^{\circ} \mathrm{c}$ until tested.

\section{Immunochromatographic assay}

At first the test kit (Anigen Rapid Bovine TB Ab test kit) was removed from the foil pouch and placed on a flat, dry surface. Ten $\mu 1$ (one drop) serum was added to the sample hole marked "S" on the test device with a 
capillary tube or single cannel microtiter pipette and waited for 1 minute and then added 3 drops of the developing buffer into the developing buffer hole. Appearance of a purple band in the result window of the test kit within 20 minutes indicates positive result and indicating control band only in negative result. In positive cases, intensity of the faint purple band appeared within 20 minutes. No result was read after 30 minutes.

\section{Data collection}

A questionnaire was developed and all information relating the study objectives was recorded. Data on animal ID, herd size, age, sex, breed, coughing history, body weight, health condition, parity and husbandry system were recorded.

\section{Statistical analysis}

Data were entered in Microsoft Excel 2007 and transferred to R 2.14.2 (The R Foundation for Statistical Computing, Vienna, Austria). Descriptive statistics were obtained using Data Mining package of the software $\mathrm{R}$ 2.14.2. Risk factors analysis was done using stepwise backward elimination method as described by Dohoo et al. (2003). A total 101 cattle from 56 households were tested with rapid bTB diagnostic kit. The overall prevalence of bovine tuberculosis was 5.9\% (95\% Confidence interval: 2.2-12.5). The result of bivariable logistic regression is presented in Table 1 . History of coughing was significantly associated with bovine tuberculosis seropositivity $(\mathrm{p}<0.009)$.

\section{RESULT AND DISCUSSION}

A total of 101 cattle from 56 households were tested with rapid bTB diagnostic kit. The overall prevalence of bovine tuberculosis was 5.9\% (95\% Confidence interval: 2.2-12.5) (Table 1).

Table 1. Results of bivariable logistic regression of bovine tuberculosis in cattle in Mymensingh sadar

\begin{tabular}{|c|c|c|c|c|c|}
\hline Variables & $\begin{array}{l}\text { No. of cattle } \\
\text { examined }\end{array}$ & $\begin{array}{l}\text { No. of cattle } \\
\text { positive to bTB } \\
\text { test }\end{array}$ & $\begin{array}{c}\text { Prevalence } \\
\text { (\%) }\end{array}$ & Z-value & p-value \\
\hline \multicolumn{6}{|l|}{ Herd size } \\
\hline One to four & 54 & 2 & 3.7 & Reference & - \\
\hline More than 4 & 47 & 4 & 8.5 & 1.8 & 0.08 \\
\hline \multicolumn{6}{|l|}{ Age } \\
\hline Young ( $<3$ years) & 23 & 1 & 4.35 & Reference & \\
\hline Adult ( $>3$ years) & 78 & 5 & 6.41 & 0.40 & 0.70 \\
\hline \multicolumn{6}{|l|}{ Health condition } \\
\hline Good $(\mathrm{BCS}=>3-4)$ & 36 & 0 & 0 & Reference & - \\
\hline Medium $(\mathrm{BCS}=2-3)$ & 45 & 2 & 4.44 & 0.01 & 0.99 \\
\hline Poor $(\mathrm{BCS}=1-2)$ & 20 & 4 & 20.0 & 0.01 & 0.99 \\
\hline \multicolumn{6}{|l|}{ History of coughing } \\
\hline No & 85 & 4 & 4.70 & Reference & - \\
\hline Yes & 16 & 2 & 12.5 & 2.6 & 0.009 \\
\hline \multicolumn{6}{|l|}{ Parity } \\
\hline Few ( $\leq 3$ calves $)$ & 47 & 3 & 6.4 & Reference & - \\
\hline Moderate (4-7 calves) & 27 & 2 & 7.4 & -0.21 & 0.83 \\
\hline Many ( $>7$ calves) & 4 & 0 & 0 & -0.01 & 0.99 \\
\hline Zero $(0$ calf $)$ & 23 & 1 & 4.35 & -0.5 & 0.62 \\
\hline \multicolumn{6}{|l|}{ Husbandry System } \\
\hline Extensive & 12 & 1 & 8.33 & Reference & - \\
\hline Intensive & 31 & 1 & 3.22 & -0.95 & 0.34 \\
\hline Semi-intensive & 58 & 4 & 6.9 & -1.8 & 0.07 \\
\hline \multicolumn{6}{|l|}{ Breed } \\
\hline Cross & 89 & 5 & 5.61 & Reference & - \\
\hline Local & 12 & 1 & 8.33 & 1.6 & 0.11 \\
\hline Overall prevalence & 101 & 6 & \multicolumn{3}{|c|}{$5.9(2.2,12.5)^{*}$} \\
\hline
\end{tabular}

* 95\% Confidence Interval in parenthesis $\quad \mathrm{BCS}=$ Body condition score 


\section{Mondal and others}

The overall prevalence $(5.9 \%)$ of bovine TB reported in this study is comparable with the reports of Pharo et al. (1981) and Samad and Rahman (1986). However, it was lower than the reports of Rahman and Samad (2008), Ameni et al. (2007), Islam et al. (2007) and Swai et al. (2006). The differences may be due to size of the sample, type of diagnostic test used, husbandry system etc. The result of bivariable logistic regression is presented in Table 1. History of coughing was significantly associated with bovine tuberculosis seropositivity $(\mathrm{p}<0.009)$ which is in agreement with Sauter and Morris (1995).

Table 2. Risk factors identified in multiple logistic regression model of bovine tuberculosis in cattle in Mymensingh sadar

\begin{tabular}{|llll|}
\hline Risk factors & Odds Ratio & $\mathbf{9 5 \%} \mathbf{C I}^{*}$ & p-value \\
\hline Herd size & - & & - \\
One to four & 5.9 & - & 0.03 \\
More than 4 & & $1.2,28.6$ & - \\
History of coughing & - & - & 0.005 \\
No & 8.9 & $1.9,42.1$ & \\
Yes & & & \\
\hline
\end{tabular}

Other than coughing, herd size, husbandry system and breed were included in multiple logistic regressions as their p-values were below 0.15 . Risk factors identified in multiple logistic regression analysis is shown in Table 2. Multiple logistic regression analysis revealed significant association of bovine tuberculosis with herd size (more than 4) (Odds Ratio, $\mathrm{OR}=5.9, \mathrm{p}=0.03)$ and history of coughing $(\mathrm{OR}=8.9, \mathrm{p}=0.005)$ (Table 2) which similar to the report of other authors (Griffin et al., 1993; Neill et al., 1989, Costello et al., 1998, Ameni et al., 2006). Prevalence of bTB is frequently associated with close contact in shared airspace which increases transmission of bTB from one cattle to another in a herd.

\section{CONCLUSIONS}

The main results from this study emphasize the risk factors for bovine tuberculosis in cattle. The potential independent risk factors identified in this study were herd size (more than 4) and history of coughing. It was found that the prevalence of bovine tuberculosis in cattle increases with the increase in numbers of cattle in herd, poor health condition and history of coughing. It would be impracticable to keep the herd size minimum. However, remedial action can be taken by maintaining the cattle in a herd with adequate floor space and better ventilation facilities.

\section{ACKNOWLEDGEMENT}

The authors are grateful to Seed Bull Research Project under Department of Animal Breeding and Genetics, Bangladesh Agricultural University, Mymensingh-2202 for funding to conduct this study.

\section{REFERENCES}

1. Ameni G, Aseffa A, Engers H, Young D, Gordon S, Hewinson G and Vordermeier M (2007). High prevalence and increased severity of pathology of bovine tuberculosis in Holsteins compared to zebu breeds under field cattle husbandry in central Ethiopia. Clinical and Vaccine Immunology 14: 1356-1361.

2. Ameni G, Aseffa A, Engers H, Young D, Hewinson G and Vordermeier M (2006). Cattle husbandry in Ethiopia is a predominant factor affecting the pathology of bovine tuberculosis and gamma interferon responses to mycobacterial antigens. Clinical and Vaccine Immunology 13: 1030-1036.

3. Aranaz A, Lie'bana E, Mateos A, Domi'nguez L, Vidal D, Domingo M, Gonzolez O, Rodriguez FEF, Bunschoten A,Van Embden JDA and Cousins D (1996). Spacer oligonucleotide typing of Mycobacterium bovis strains from cattle and other animals, a tool for studying epidemiology of tuberculosis. Journal of Clinical Microbiology 34: 2734-40.

4. Cetinkaya B, Erdogan HM and Morgan KL, (1997). Risk factors for bovine paratuberculosis. The univariate analysis of risk factors for bovine paratuberculosis. Turk Veterinerlik-ve-Hayvancilik dergisi 21: 297-302. 
5. Chandra Hav, Yukio M, Dhakal M, Besnet B, Sato T, Nagai A, Kato M, Kozawa K, Yamamoto S and Kimura H (2007). Isolation of Mycobacterium spp. from milking buffaloes and cattle in Nepal. Journal of Veterinary Medicine Science 69: 819-25.

6. Costello E, Doherty ML, Monaghan ML, Quigley FC and O'Reilly PF (1998). A study of cattle-to-cattle transmission of Mycobacterium bovis infection. The Veterinary Journal 155: 245-50.

7. Dohoo IR, Martin W and Stryhn H (2003). Veterinary Epidemiologic Research. AVC Inc. Charlottetown, Prince Edward Island, Canada.

8. Griffin JM, Hahesy T, Lynch K, Salman MD, McCarthy J and Hurley T (1993). The association of cattle husbandry practices, environmental factors and farmer characteristics with the occurrence of chronic bovine tuberculosis in dairy herds in the Republic of Ireland. Preventive Veterinary Medicine 17: 145-160.

9. Hutchings MR and Harris S, (1997). Effects of farm management practices on cattle grazing behavior and the potential for transmission of bovine tuberculosis from badgers to cattle. Veterinary Journal 153: 149-162.

10. Islam MM, Siddique MAR, Haque MA, Baki MA, Majumder S, Parrish JJ and Shamsuddin M (2007). Screening some major communicable diseases of AI bulls in Bangladesh. Livestock Research Rural Development 19: 79.

11. Jark U, Ringena I, Franz B, Gerlach GF and Beyerbach M (1997). Development of an ELISA technique for serodiagnosis of bovine paratuberculosis. Veterinary Microbiology 57: 189-198.

12. Joshi DV, Sharma DR, Sodhi SS and Dhillon SS (1976). Survey of tuberculosis at a buffalo farm. Indian Journal of Animal Health 15: 27-8.

13. Khan IA, Khan A, Mubarak A and Ali S (2008). Factors affecting prevalence of bovine tuberculosis in Nili ravi buffaloes. Pakistan Veterinary Journal 28: 155-158.

14. Koo HC, Park YH, Ahn J, Waters WR, Palmer MV, Hamilton MJ, Barrington G, Mosaad AA, Park KT, Jung WK, Hwang IY, Cho SN, Shin SJ and Davis WC (2005). Use of rMPB7D protein and ESAT-6 peptide as antigens for comparison of the Enzyme-linked immunosorbent, immunochromatographic and latex based agglutination assays for serodiagnosis of bovine tuberculosis. Journal of Clinical Microbiology 43: 4498 - 4506.

15. Menzies FD and Neill SD (2000). Cattle-to-cattle transmission of bovine tuberculosis. The Veterinary Journal 160: 92-106

16. Neill SD, Hanna J, O'Brien JJ and McCracken RM (1989). Transmission of tuberculosis from experimentally infected cattle to in-contact calves. Veterinary Record 124: 269-271.

17. O'Reilly LM and Daborn CJ (1995). The epidemiology of Mycobacterium bovis infections in animals and man: a review. Tubercle and Lung Disease 1: 1-46.

18. OIE (2004). Manual of Standards for Diagnostic Tests and Vaccines of World Organization for Animal Health, $4^{\text {th }}$ edition.

19. Pharo HJ, Motalib A, Routledge SF and Alam S (1981). The prevalence of bovine tuberculosis in the Bangladesh Cattle Development Project. Bangladesh Veterinary Journal 15: 53-56.

20. Polyakov VA, Ishekenov MS and Kosenko VI (1994). Flies-one of the links in the transmission mechanism of tuberculosis in animals. Problemy Veterinarnoi Sanitari Ekdojii 93: 84-92.

21. Radostits OM, Gay CC, Blood DC and Hinchcliff KW ( 2000). Veterinary Medicine. $9^{\text {th }}$ edn, W.B. Saunders Co. Ltd., London.

22. Rahman MM and Samad MA (2008). Prevalence of Bovine tuberculosis and its effects on milk production in Red Chittagong cattle. Bangladesh Journal of Veterinary Medicine 6:175-178.

23. Samad MA and Rahman MS (1986). Incidence of bovine tuberculosis and its effect on certain blood indices in dairy cattle of Bangladesh. Indian Journal of Dairy Science 39: 3 - 6.

24. Sauter CM and Morris RS (1995). Dominance hierarchies in cattle and red deer (Cervus elaphus): their possible relationship to the transmission of bovine tuberculosis. New Zealand Veterinary Journal 43: 301-305.

25. Swai ES , Shirima G, Bwanga S and Moshy W (2006). Bovine tuberculosis survey in urban and peri-urban dairy farms in coastal humid region of Tanga,Tanzania. Bulletin of Animal Health and Production in Africa 54: 75-78.

26. Valente C, Cuteri V, Giandomenico RQ, Gialletti L and Franciosini MP (1997). Use of an experimental chicks model for paratuberculosis enteritis (Johne's disease). Veterinary Research 28: 239-46. 